\title{
Zulliger (CS) in Assessing the Relational Maturity of Children ${ }^{1}$
}

\author{
Anna Elisa Villemor-Amaral ${ }^{2}$ \\ Universidade São Francisco, \\ Itatiba-SP, Brazil
}

\author{
Philipe Gomes Vieira \\ Universidade São Francisco, \\ Itatiba-SP, Brazil
}

\begin{abstract}
Relational maturity is an important aspect to be considered in the evaluation of children. Its development in children is considered related to sex and chronological age. The present study aimed to seek evidence of validity for the Zulliger test (Comprehensive System - CS) in the evaluation of maturity for interpersonal relationships in children. A total of 566 children, both sexes, of which $52.8 \%$ were girls, were submitted to the Zulliger test (CS). For comparison according to age, a subsample was extracted, composed of two groups of six and 12-year-olds, totaling 115 children. The analysis revealed statistically significant differences in the variables $\mathrm{H},(\mathrm{H}), \mathrm{A}, \mathrm{Ad},(\mathrm{A}), \mathrm{M}, \mathrm{FC}$ and AG. Results show findings in favor of using the Zulliger test (CS) in the evaluation of maturity for interpersonal relationships in children.
\end{abstract}

Keywords: psychological assessment, children's personality, projective techniques, Zulliger test, personality traits

\section{Zulliger (SC) na Avaliação da Maturidade Relacional de Crianças}

\begin{abstract}
Resumo: A maturidade relacional é um aspecto importante a ser considerado na avaliação infantil. Acredita-se que o seu desenvolvimento em crianças esteja atrelado às variáveis sexo e idade cronológica. Assim, o presente estudo teve como objetivo buscar evidências de validade para o teste de Zulliger (Sistema Compreensivo - SC) na avaliação da maturidade para o relacionamento interpessoal em crianças. Um total de 566 crianças, ambos os sexos, sendo 52,8\% meninas, foi submetido ao teste de Zulliger (SC). Para comparação em função da idade, extraiu-se uma subamostra composta por dois grupos com seis e 12 anos, totalizando 115 crianças. As análises revelaram diferenças estatisticamente significativas para as variáveis $\mathrm{H},(\mathrm{H}), \mathrm{A}, \mathrm{Ad},(\mathrm{A}), \mathrm{M}, \mathrm{FC}$ e $\mathrm{AG}$. Os resultados evidenciam achados em favor da utilização do teste de Zulliger (SC) na avaliação da maturidade para o relacionamento interpessoal em crianças.

Palavras-chave: avaliação psicológica, personalidade da criança, técnicas projetivas, teste de Zulliger, traços de personalidade

\section{Zulliger (SC) en la Evaluación de la Madurez Relacional de los Niños}

Resumen: La madurez relacional es un aspecto importante a considerar en la evaluación de los niños. Se cree que su desarrollo en niños esté relacionado con el sexo y la edad cronológica. Este estudio tuvo como objetivo buscar evidencias de validez para la prueba Zulliger (Sistema Integral - SI) en la evaluación de la madurez a la relación interpersonal en los niños. Un total de 566 niños, de ambos sexos, siendo 52,8\% niñas, se sometieron a la prueba Zulliger (SI). Para la comparación de acuerdo a la edad, una sub-muestra de 115 niños se extrajo, que consiste en dos grupos, de seis y 12 años. El análisis reveló diferencias estadísticamente significativas en las variables $\mathrm{H},(\mathrm{H}), \mathrm{A}, \mathrm{AD},(\mathrm{A}), \mathrm{M}, \mathrm{FC}$ y AG. Las conclusiones muestran los resultados a favor de la utilización de la prueba Zulliger (SI) en la evaluación de la madurez a la relación interpersonal en los niños.
\end{abstract}

Palabras clave: evaluación psicológica, personalidad de los niños, técnicas proyectivas, prueba Zulliger, rasgos de personalidad

The psychological assessment of children is a complex process, whose purposes are defined based on a demand. A recurring demand in clinical psychology has been diagnostic assessment, which permits clarifying the child's potentials and weaknesses, consequently supporting satisfactorily appropriate decision making (Schelini, Gomes, \& Wechsler, 2006). In that context, the peculiarities inherent in the childhood development phases need to be considered so that the assessment of children can contribute to their appropriate maturing, avoiding or mitigating the emergence of psychopathologies (Pérez-Ramos, 2000; Tavella \& Villemor-Amaral, 2014).

\footnotetext{
${ }^{1}$ Support: National Council for Scientific and Technological Development (CNPq Grant \# 304504/2010-6).

${ }^{2}$ Correspondence address:

Anna Elisa Villemor-Amaral. Universidade São Francisco. Rua Alexandre Rodrigues Barbosa, 45, Centro. CEP 13251-900, Itatiba-SP, Brazil. E-mail: anna.villemor@usf.edu.br
}

Davoglio, Gauer, Jaeger and Tolotti (2012) highlight the importance of acknowledging children as beings whose subjectivity is being constructed and developed, especially concerning the personality construct, so that neglecting this premise in the course of the assessment would produce inferences loaded with mistakes, which would merely serve to segregate the subject in question. As a counterpart, to avoid mistaken conclusions, different associated psychological investigation techniques should be used, such as psychological tests, interviews with the people involved in care for the child and observations. Thus, one could promote a contextualized understanding of the child's functioning, without labeling or stigmatizing him/her, as suggested by Nunes, Teixeira and Deakin (2010) and Schelini et al. (2006).

Among the core aspects that need to be discussed in the course of the child's assessment process, the interpersonal relationship stands out. Weiner (2000) defined it as the way in 
which people try to bond with others, expressed by attitudes that are intended to insert them in the social context. The interpersonal relationship can be considered healthy, as the author highlights, when the subject is capable of maintaining satisfactory levels of interest and engagement, allowing him/ her to achieve a balance between cooperative and empathetic as well as assertive and competitive actions. In childhood, the establishment of relational bond, according to Garcia and Pereira (2008), can take place in the harmful or constructive sense. The same authors (2008) consider that, as children get older and develop appropriately, their maturity for relationships improves, becoming more empathetic, altruistic and stable in their behavior towards others, contributing to the establishment of positive and healthy bonds.

Also concerning the development of maturity for interpersonal relationships in children, another variable that should be respected is sex, as girls tend to evolve before boys (Leitão, 1999). It should be highlighted, however, that research in the field of Psychological Assessment generally does not truly consider the gender identity but the biological element, sex, which represents a concrete variable that is easy to observe.

Leitão (1999) discusses that girls give more signs of emotional involvement in people's problems and also tend to feel more responsible for them. The same author defends that female ethics are more focused on care and interpersonal concerns, while male ethics is linked to abstract principles of justice. Thus, boys tend to be more to the development of rational control over emotions. In addition, the author argues that girls gain empathetic skills faster, as well as the sense of connection with others and the reduced expression of anger and aggressiveness, while boys, as they get older, also develop these skills, even if somewhat later than girls.

One of the tools that can be useful to assess the quality of the relationships the children establish, as well as their maturity for this kind of engagement, is the Zulliger test, by means of the Comprehensive System (CS). Traditionally considered to be a projective technique, Hans Zulliger created this ink blot test in 1948 to assess components of how the personality functions, addressing aspects of its dynamics and structure, as well as fantasies and underlying anxieties (Villemor-Amaral \& Primi, 2009). It should be highlighted that this test originated in the classical and internationally used Rorschach method, whose creator Hermann Rorschach already clearly discussed the relation between colors and affects, emotions and interpersonal relationships. According to him, the way the subject reacts to a colored stimulus when saying what the blot looks like is similar to the way he/she reacts to affections (Rorschach, 1921/1978).

In the Zulliger test (CS), there are different variables that grant access to components linked to facts that indicate appropriate interpersonal relationship conditions, suggesting the appropriate development of maturity. As VillemorAmaral and Primi (2009) highlight, like in the Rorschach, in the Zulliger test, responses determined by the impression of human movement, coded as M, evidence a strong projective loading, since this element, as opposed to the colors, shadigns and outlines of the forms, is not present on the stimuli, being an extrapolation in view of inert ink blots. These responses reveal empathy and sensitivity towards other people's needs, representing fundamental components for the establishment of an appropriate social perception.

Also in the Zulliger test, according to Villemor-Amaral and Primi, responses determined by the chromatic colors, whether accompanied or not by a precise form, reveal how the subject copes with emotions and affections. Rorschach (1921/1978) argued that, when answering strictly based on the pure color, without association with a form, the subject revealed more primitive states of emotional development. On the other hand, predominantly shape-based responses with a color are supposed to be linked to emotional stability through reason. In line with premises by Hermann Rorschach, Malone et al. (2013), and with the Zulliger, Villemor-Amaral and Primi highlight that, when shape predominates over color, responses in which objects are expressed with a well-defined shape associated with the color, coded as CF, there are signs of rational resources that serve to appropriately contain the emotions. On the opposite, responses determined by colors that overlap with the forms, or even without a formal aspect, coded as CF and $\mathrm{C}$, respectively, reveal precarious control and proneness to abrupt and impulsive emotional manifestations.

Villemor-Amaral and Primi (2009) clarify that, in the Comprehensive System (CS) coding for the Rorschach method, also used for the Zulliger test, responses whose codes are in collaborative movement are coded as COP and represent the positive quality perceived in the relational bonds. On the other hand, when the movement is expressed as an ongoing aggressive action, coded as AG, this suggests potential hostility in the way interpersonal contacts are conceived.

The human content responses receive specific codes determined according to how the subject perceives them. The expression of complete humans, perceived with realistic characteristics, is coded as $\mathrm{H}$. On the opposite, when this content comes with fantastic and/or para-human characteristics, it is coded as $(\mathrm{H})$. Other subcategories within human contents emerge in function of the fragmentation of perception, like expressions of real human or para-human body, respectively coded as $\mathrm{Hd}$ and ( $\mathrm{Hd})$. It should be highlighted that the fragmented human and/or para-human perceptions demonstrate immaturity in personal contacts, and can also be linked to narcissistic manifestations, which can be equally understood as precarious maturity development (Exner \& Sendín, 1999; Villemor-Amaral \& Primi, 2009). In that sense, the authors defend the idea that $\mathrm{H}$ represents the best expression of maturing of the relational interests among the variables in this cluster.

Also regarding the perception of human contents, Viglione, Perry, Giromini, and Meyer (2011) highlight the quality of these representations, which can be coded as GHR, when there is a good representation of human, or PHR, when they are impoverished. Villemor-Amaral and Primi (2009) already agreed to the idea that GHR responses suggest better possibilities of well adapted and matured interpersonal contact, being thus expected more 
frequently, surpassing PHR in adult subjects, in accordance with Meyer, Viglione, Mihura, Erard e Erdberg (2011).

The perceptions of animal contents are consolidated as the most frequent in the Zulliger test (CS). Their increase is associated with immaturity and less cognitive sophistication, mainly if the fragmentations of the figures surpass the contents seen as complete (Villemor-Amaral \& Primi, 2009). For this cluster, different codes also exist, according to the degree of reality and integration the subject imprints on his/her perceptual constructions. Animal contents expressed in an integrated manner and perceived as realistic characteristics are coded as A, while animals with fantastic, fictitious and/or supernatural connotations are coded as (A). When these contents are partially visualized, i.e. in a fragmented manner, the codes are Ad and (Ad), respectively, for details of real animals and details of fictitious animals. It should be highlighted that fragmented and/or unreal perceptions of animal contents, surpassing integrated expressions, strengthen the hypothesis of immaturity.

For psychologists to use the Zulliger (CS) in their professional practice, orientations should be sought which have been published in the technical manual by Villemor-Amaral and Primi, whose current version only contains norms for the evaluation of adults. Nevertheless, although no standardizing expectations have been published for its use to assess children, some validity studies for this context have been undertaken, which have revealed promising data in favor of the test.

A search in the Brazilian scientific databases SciELO and Pepsic, using only the key word "Zulliger", revealed seven articles, published as from 2010, in which the test was discussed according to the comprehensive system (CS). Nevertheless, five of them discuss its use in adults (Fazendeiro \& Novo, 2012; Franco \& Villemor-Amaral, 2012; Grazziotin \& Scortegagna, 2012, 2013; VillemorAmaral \& Machado, 2011). Two of the publications found through the abovementioned search were also retrieved when using the descriptors "Zulliger" and "Children". These publications will be discussed in further detail next.

Tavella and Villemor-Amaral (2014) aimed to verify whether the affective and cognitive indicators assessed by means of the Zulliger test (CS) are capable of identifying children with different creative potentials, assessed using the Test of Figural Creativity for Children (TFCC), concluding that they are sensitive to distinguish children with different creativity levels. In another publication, Villemor-Amaral and Quirino (2013) attempted to correlate the variables FC, CF and C in the Zulliger test (CS), linked to emotional functioning, with the type of formal aspect obtained on Pfister's Colored Pyramids test, which in turn refers to cognitive skills. The results achieved are discussed in the light of the psychoemotional development theories, addressing phases that range from childhood to the start of adolescence.

In sum, although few studies have been published on the use of the Zulliger (CS) in children, none of them discusses evidence of validity for the test in the assessment context of maturity for interpersonal relationships, which justifies the proposal of this study. Thus, the codes linked to the responses in the Zulliger test (CS), as presented, evidence the quality of a certain subject's relational investments, suggesting his/her maturity level for interpersonal relationships. Therefore, the goal in this study is to verify whether statistically significant differences exist in the variables that suggest the maturity for interpersonal relationships in male and female children. Next, the children are divided in two groups, defined by the ages of six and 12 years.

The underlying hypotheses were that the group of younger children would reveal a higher frequency of some of the variables $\mathrm{CF}, \mathrm{C}, \mathrm{Hd},(\mathrm{H}),(\mathrm{Hd}), \mathrm{Ad},(\mathrm{A}),(\mathrm{Ad}), \mathrm{AG}$ and PHR, considering that, theoretically, they present a lower degree of maturity for interpersonal contacts. On the opposite, older children would evidence a higher frequency for some of the variables, M, FC, H, A, GHR and COP, suggesting maturity for interpersonal relationships. Similarly, it is supposed that, when boys and girls are compared, a similar trend can be identified, considering that girls are expected to present higher scores on the variables linked to maturity, except for FC, which in theory is expected to score higher among boys.

\section{Method}

\section{Participants}

For this study, a database was used that contained 566 Zulliger Test (CS) protocols of male and female children, in which $52.8 \%(n=299)$ of the sample were girls. Ages ranged between six and 14 years. The largest part, $21.6 \%$ $(n=122)$, were children aged 11 years. The total sample selection criterion was that the child's age should be compatible with the school year, without a history of search for psychological and/or psychiatric help, as informed by the pedagogical advisor or school principal, based on the children's histories. The detailed distribution of the ages in function of sex is displayed in Table 1.

Table 1

Detailed Distribution of Ages in Function of Sex

\begin{tabular}{|c|c|c|c|c|c|c|c|c|c|c|c|}
\hline & & \multicolumn{9}{|c|}{ Age } & \multirow{2}{*}{ Total } \\
\hline & & 6 & 7 & 8 & 9 & 10 & 11 & 12 & 13 & 14 & \\
\hline \multirow{2}{*}{ Sex } & Female & 31 & 29 & 25 & 33 & 49 & 67 & 35 & 30 & 0 & 299 \\
\hline & Male & 18 & 26 & 11 & 40 & 43 & 55 & 31 & 26 & 17 & 267 \\
\hline Total & & 49 & 55 & 36 & 73 & 92 & 122 & 66 & 56 & 17 & 566 \\
\hline
\end{tabular}


To compare the performance on the Zulliger (CS) test in function of the age ranges, a sub-sample was extracted from the database that contained 115 children, divided in $42.6 \%$ $(n=49)$ aged six years and $57.4 \%(n=66)$ aged 12 years. All children were regularly enrolled in school years compatible with their ages, respectively in the first and seventh year of primary education.

\section{Instument}

Zulliger Test-Comprehensive System (CS). This test consists of a set of three cards with artistically semistructured inkblots. While the first is achromatic, the second consists of different colors and the third black, grey and red. With regard to its administration, Villemor-Amaral and Primi (2009) highlight that it tends to be fast and rarely exceeds 30 minutes, divided in two phases. The first, called Response Phase, consists in the presentation of the cards, one at a time and in a preset order, followed by the question "what might this be?" Thus, the subject is expected to look at the stimuli on the care and express what each blot, whether as a whole or in its respective details, looks like. As the subject constructs his/her responses, the examiner registers everything being said on the protocol. Then, the second phase starts, known as Inquiry. During this phase, the examiner goes over the cards with the subject to register in what location each response was constructed, using a standardized sheet with the printed ink blots, as well as to clarify what in the ink blots determined the visualization of the contents.

\section{Procedure}

Data collection. The database was composed in the course of eight years of research, when the Pfister test and a form with the children's sociodemographic data were also applied. Researchers from the research group with proper training for the data collection administered the Zulliger Test (CS) alternately after and before the Pfister test. The tools were applied during individual sessions, at rooms schools from the public and private networks in the State of São Paulo had made available. Each data collection took about 20 minutes per child. Next, the researchers responsible for the collection properly coded the Zulliger (CS) protocols, in accordance with the orientations published in the technical manual by Villemor-Amaral and Primi (2009). Each protocol was coded independently at least twice and, in case of disagreements in the coding, these were discussed with the research coordinator to reach a consensus. Then, the data were put into a worksheet in Statistical Package for Social Sciences (SPSS) for statistical analyses.

Data analysis. To proceed with the statistical analyses to compare the mean performance of the two groups defined according to sex, Student's t-test was used to verify whether statistically significant mutual differences existed concerning the variables $\mathrm{H}, \mathrm{Hd},(\mathrm{H}),(\mathrm{Hd}), \mathrm{M}, \mathrm{FC}, \mathrm{CF}, \mathrm{C}, \mathrm{A}, \mathrm{Ad},(\mathrm{A}),(\mathrm{Ad})$, GHR, PHR, AG and COP. The magnitude of the differences was measured using Cohen's $d$, considering the parameters of weak, moderate and strong magnitude, respectively, up to .29; between .30 and .49; and as from .50, as discussed by Cohen (1992). The same analysis was developed for the ages of six and 12 years.

\section{Ethical Considerations}

This study was submitted to the Research Ethics Committee of the Universidade São Francisco and received approval (CAAE n. 0078.0.142.000-07). The Zulliger test (CS) was only administered if the children's parents signed the Free and Informed Consent Form to authorize their participation.

\section{Results}

The children's mean performance on the variables related to the maturity for interpersonal relationships in the Zulliger test (CS) in function of sex was compared for the sake of initial analysis. The data in Table 2 present the two groups' mean performance, as well as the result of the comparisons.

Table 2

Comparison Between Performance of Girls and Boys on Indicators Related to Maturity for Interpersonal Relationship

\begin{tabular}{|c|c|c|c|c|c|c|c|}
\hline & Sex & $n$ & $M$ & $S D$ & $t$ & Cohen's $d$ & $p$ \\
\hline \multirow{2}{*}{$\mathrm{FC}$} & Female & 299 & 0.21 & 0.563 & \multirow{2}{*}{-2.803} & \multirow{2}{*}{0.24} & \multirow{2}{*}{.005} \\
\hline & Male & 267 & 0.36 & 0.641 & & & \\
\hline \multirow{2}{*}{$\mathrm{CF}$} & Female & 299 & 0.42 & 0.702 & \multirow[b]{2}{*}{-0.664} & \multirow{2}{*}{0.05} & \multirow{2}{*}{.507} \\
\hline & Male & 267 & 0.46 & 0.689 & & & \\
\hline \multirow{2}{*}{$\mathrm{C}$} & Female & 299 & 0.12 & 0.408 & \multirow{2}{*}{-0.514} & \multirow{2}{*}{0.04} & \multirow{2}{*}{.608} \\
\hline & Male & 267 & 0.14 & 0.433 & & & \\
\hline \multirow{2}{*}{ M } & Female & 299 & 0.55 & 0.820 & \multirow{2}{*}{-0.138} & \multirow{2}{*}{0.01} & \multirow{2}{*}{.890} \\
\hline & Male & 267 & 0.55 & 0.746 & & & \\
\hline
\end{tabular}




\begin{tabular}{|c|c|c|c|c|c|c|c|}
\hline & Sex & $n$ & $M$ & $S D$ & $t$ & Cohen's $d$ & $p$ \\
\hline \multirow{2}{*}{$\mathrm{H}$} & Female & 299 & 1.10 & 0.997 & \multirow{2}{*}{2.010} & \multirow{2}{*}{0.16} & \multirow{2}{*}{.045} \\
\hline & Male & 267 & 0.94 & 0.893 & & & \\
\hline \multirow{2}{*}{$(\mathrm{H})$} & Female & 299 & 0.31 & 0.608 & \multirow{2}{*}{-1.480} & \multirow{2}{*}{0.12} & \multirow{2}{*}{.139} \\
\hline & Male & 267 & 0.39 & 0.653 & & & \\
\hline \multirow{2}{*}{ Hd } & Female & 299 & 0.34 & 0.703 & \multirow{2}{*}{-1.361} & \multirow{2}{*}{0.11} & \multirow{2}{*}{.174} \\
\hline & Male & 267 & 0.43 & 0.798 & & & \\
\hline \multirow{2}{*}{$(\mathrm{Hd})$} & Female & 299 & 0.05 & 0.253 & \multirow{2}{*}{0.437} & \multirow{2}{*}{0.03} & \multirow{2}{*}{.662} \\
\hline & Male & 267 & 0.04 & 0.208 & & & \\
\hline \multirow{2}{*}{ A } & Female & 299 & 3.63 & 2.053 & \multirow{2}{*}{2.098} & \multirow{2}{*}{0.17} & \multirow{2}{*}{.036} \\
\hline & Male & 267 & 3.28 & 1.875 & & & \\
\hline \multirow{2}{*}{ (A) } & Female & 299 & 0.09 & 0.314 & \multirow{2}{*}{-1.328} & \multirow{2}{*}{0.11} & \multirow{2}{*}{.185} \\
\hline & Male & 267 & 0.13 & 0.421 & & & \\
\hline \multirow{2}{*}{ Ad } & Female & 299 & 0.24 & 0.562 & \multirow{2}{*}{-2.442} & \multirow{2}{*}{0.20} & \multirow{2}{*}{.015} \\
\hline & Male & 267 & 0.37 & 0.767 & & & \\
\hline \multirow{2}{*}{ (Ad) } & Female & 299 & 0.01 & 0.082 & \multirow{2}{*}{-0.113} & \multirow{2}{*}{0.01} & \multirow{2}{*}{.910} \\
\hline & Male & 267 & 0.01 & 0.086 & & & \\
\hline \multirow{2}{*}{$\mathrm{AG}$} & Female & 299 & 0.21 & 0.504 & 1011 & 008 & 312 \\
\hline & Male & 267 & 0.25 & 0.530 & 1.001 & & \\
\hline & Female & 299 & 0.16 & 0.435 & & & \\
\hline CUP & Male & 267 & 0.15 & 0.354 & 0.431 & 0.03 & $.06 /$ \\
\hline & Female & 299 & 1.17 & 0.959 & & & \\
\hline GHK & Male & 267 & 1.08 & 0.930 & $1.10 /$ & 0.09 & .208 \\
\hline & Female & 299 & 0.77 & 1.018 & & & \\
\hline Гпи & Male & 267 & 0.93 & 1.087 & -1.120 & 0.14 & $.00 J$ \\
\hline
\end{tabular}

As can be observed in Table 2, the boys' mean score on the FC variable was higher than the girls', revealing a weak but statistically significant difference. On the other hand, as observed in the same table, the variables $\mathrm{H}$ and $\mathrm{A}$, linked to the perception of integrated human and animal contents, were more frequent in the female group, sufficient to demonstrate an equally weak but statistically significant difference. On the opposite, the boys scored higher on the variable Ad, linked to perceptual constructions of details of real animals, revealing a discrepancy that is considered weak but significant.

In parallel with these analyses, the children's performance on the same variables was compared in function of the ages six and 12 years. The data presented in Table 3 reveal how the two age groups differ in the variables selected for this study.

Although the variable $\mathrm{H}$ revealed no statistically significant differences between children aged six and 12 years, as observed in Table 3, its coefficient was moderate. On the opposite, the variable $(\mathrm{H})$, related to human contents with fanciful or para-human characteristics, signaled a higher frequency in the group of younger children, evidencing strong and statistically significant differences when compared to older children. The performance analysis of both groups of children with regard to the variable $M$, which consists in the responses determined by the impression of human movement, supports that result, as this variable remained present with a higher frequency in the group of older children, whose difference is moderate and statistically significant, as presented in Table 3.

The variable attributed to the AG responses, related to the impression of aggressive movements, was more frequent in the group of younger children. Although the difference in that comparison did not demonstrate statistical significance, it has shown a moderate effect size. 
Table 3

Comparison Between Performance of Younger and Older Children on Indicators Related to Maturity for Interpersonal Relationships

\begin{tabular}{|c|c|c|c|c|c|c|c|}
\hline & Age & $n$ & $M$ & $S D$ & $t$ & Cohen's $d$ & $p$ \\
\hline \multirow{2}{*}{$\mathrm{H}$} & 6 & 49 & 0.65 & 0.805 & \multirow{2}{*}{-1.877} & \multirow{2}{*}{0.35} & \multirow{2}{*}{.063} \\
\hline & 12 & 66 & 0.95 & 0.885 & & & \\
\hline \multirow{2}{*}{ (H) } & 6 & 49 & 0.59 & 0.888 & \multirow{2}{*}{2.812} & \multirow{2}{*}{0.53} & \multirow{2}{*}{.006} \\
\hline & 12 & 66 & 0.23 & 0.490 & & & \\
\hline \multirow{2}{*}{$\mathrm{Hd}$} & 6 & 49 & 0.43 & 0.791 & \multirow{2}{*}{0.453} & \multirow{2}{*}{0.08} & \multirow{2}{*}{.651} \\
\hline & 12 & 66 & 0.36 & 0.737 & & & \\
\hline \multirow{2}{*}{ (Hd) } & 6 & 49 & 0.06 & 0.242 & \multirow{2}{*}{0.799} & \multirow{2}{*}{0.15} & \multirow{2}{*}{.426} \\
\hline & 12 & 66 & 0.03 & 0.173 & & & \\
\hline \multirow{2}{*}{ A } & 6 & 49 & 2.92 & 1.681 & \multirow{2}{*}{-1.659} & \multirow{2}{*}{0.31} & \multirow{2}{*}{.100} \\
\hline & 12 & 66 & 3.55 & 2.213 & & & \\
\hline \multirow{2}{*}{ (A) } & 6 & 49 & 0.18 & 0.486 & \multirow{2}{*}{1.677} & \multirow{2}{*}{0.31} & \multirow{2}{*}{.096} \\
\hline & 12 & 66 & 0.06 & 0.298 & & & \\
\hline \multirow{2}{*}{ Ad } & 6 & 49 & 0.16 & 0.426 & \multirow{2}{*}{-1.302} & \multirow{2}{*}{0.24} & \multirow{2}{*}{.196} \\
\hline & 12 & 66 & 0.30 & 0.656 & & & \\
\hline \multirow{2}{*}{ (Ad) } & 6 & 49 & 0.00 & 0.000 & 1207 & 02 & 272 \\
\hline & 12 & 66 & 0.03 & 0.173 & -1.221 & 0.25 & $.2 \angle J$ \\
\hline COD & 6 & 49 & 0.08 & 0.277 & 0157 & 000 & 076 \\
\hline & 12 & 66 & 0.09 & 0.339 & 0.101 & & \\
\hline$\Delta \mathrm{C}$ & 6 & 49 & 0.22 & 0.468 & 1802 & 025 & 060 \\
\hline ת & 12 & 66 & 0.09 & 0.290 & 1.005 & 0.3 J & .000 \\
\hline CUD & 6 & 49 & 1.04 & 0.935 & $0-520$ & & 500 \\
\hline जпк & 12 & 66 & 1.14 & 0.975 & -0.529 & 0.09 & .090 \\
\hline PUP & 6 & 49 & 0.92 & 1.038 & 1417 & 026 & 150 \\
\hline भाI & 12 & 66 & 0.65 & 0.969 & 1.417 & 0.20 & .159 \\
\hline$M$ & 6 & 49 & 0.31 & 0.585 & 1040 & 026 & 050 \\
\hline IVI & 12 & 66 & 0.56 & 0.767 & -1.940 & 0.50 & .050 \\
\hline $\mathrm{EC}$ & 6 & 49 & 0.37 & 0.698 & ? & 01 & 27 \\
\hline & 12 & 66 & 0.38 & 0.627 & 0.72 & & . \\
\hline$C \mathrm{D}$ & 6 & 49 & 0.45 & 0.867 & 064 & 0,11 & 540 \\
\hline$C 1$ & 12 & 66 & 0.36 & 0.624 & 0.014 & 0.11 & .040 \\
\hline$C$ & 6 & 49 & 0.31 & 0.742 & 054 & 023 & 204 \\
\hline$c$ & 12 & 66 & 0.18 & 0.524 & 1.034 & 0.23 & .294 \\
\hline
\end{tabular}

\section{Discussion}

Despite publications on the Zulliger test $(\mathrm{CS})$ for use in children, as mentioned earlier (Tavella \& Villemor-Amaral, 2014; Villemor-Amaral \& Quirino, 2013), none of them discusses the validity of the test to assess the maturity for interpersonal relationships. In that sense, it has not been clearly demonstrated in the literature how this test can contribute to understand the functioning and organization of the childhood personality.

Based on the results obtained on the comparison between girls and boys, a higher frequency of the variable FC was revealed, linked to the predominance of shape over color in the second group, in line with the inferences by Leitão (1999). This finding reveals that the boys in the research sample show to be more inclined to concrete and logical aspects, to the detriment of affective manifestations, suggesting greater rational control over emotions. Although boys present this control faster, as illustrated by the higher average for the variable FC, on the other hand, they evidence lesser intellectual maturity and enhanced mistrust in the relationships, represented, according to Villemor-Amaral and Primi (2009), by the higher frequency of animal detail responses, coded as Ad.

According to Leitão (1999), girls express the development of empathetic ability earlier, making them more mature than 
boys to deal with external feelings in interpersonal contacts. This theoretical element tends to be confirmed in the research sample, as the group of girls demonstrated a higher average of complete and real human content answers, coded as $\mathrm{H}$, substantially different from the boys. Villemor-Amaral and Primi affirm that the predominance of this variable clearly reveals the stable interest in maintaining healthy interpersonal relationships.

Among the animal content variables, which reflect lesser cognitive wealth, the answers coded as A indicate better possibilities of maturing (Villemor-Amaral \& Primi, 2009). This conceptual element is empirically confirmed in this research, as the group of girls, theoretically associated with greater maturity for interpersonal relationships (Leitão, 1999), revealed a higher average than the male group.

Concerning the comparisons between the groups of younger and older children, although no statistically significant difference was found for the variable $\mathrm{H}$, linked to the interest in interpersonal relationships, in accordance with VillemorAmaral and Primi (2009), the magnitude highlighted by Cohen's $d$ is moderate, indicating that the higher average perceived in the second group appoints greater relational maturity, as theoretically expected. This finding strengthens the premise by Garcia and Pereira (2008), who argue that, as age advances, children become more prone to the development of healthy interpersonal relationships, in view of their improved empathy and greater stability in their way of acting. An opposite trend was identified for the frequency of para-human content responses (H) which, according to Villemor-Amaral and Primi, is related to the immature and impaired interpersonal interest. The group of six-year-old children scored higher on this variable, showing a substantial difference from the 12-year-olds.

The variable $\mathrm{M}$, attributed to the responses determined by the impression of human movement, also showed a statistically significant difference based on the comparison between the two age groups, with a higher coefficient in the group of older children. Villemor Amaral and Primi discuss that this variable is linked to the manifestation of empathy and the healthy and matured relational investment. This interpretation can be applied to the current empirical data, which support the premises by Garcia and Pereira (2008) about the improved maturity for interpersonal relationships that tends to emerge as age advances.

Six-year-old children, once again demonstrating a lesser degree of maturity, presented higher mean scores on the complete and real animal content answers, as well as para-animal content answers, coded as A and (A). Both types of responses are related to more primitive cognitive development, in accordance with Villemor-Amaral and Primi (2009). In the group mentioned, this finding does not appoint cognitive problems at the pathological level but, on the opposite, corresponds to this phase of life. Nevertheless, it should be highlighted that the results of the comparisons between the age groups for these variables were unable to produce statistically significant data. On the other hand, they revealed moderate coefficients, showing that, to some extent, they are sensitive to disclose children's maturing.

Another important finding that is in accordance with the hypotheses is the higher average on the aggressive movement responses, coded as AG in the group of younger children. Although no statistically significant difference was revealed, the effect size was moderate. Hence, it is considered that manifestations of aggressiveness, in line with Villemor-Amaral and Primi, expressed by the identification of this variable, can reveal the maturity for interpersonal relationships in children, as they will be prone to control primitive reactions, as Garcia and Pereira (2008) highlight, when they evolve chronologically.

It is important to emphasize that, although the analysis results for the other variables in the Zulliger test (CS) do not support the established hypotheses, as no data were produced that showed statistically significant differences between the subgroups compared, the expected trends are observed. In that sense, the test variables used to guide this study may to some extent also be useful to understand aspects related to the maturity for interpersonal relationships in children.

As a research limitation, one could highlight the lack of comparison between the groups using other psychological assessment measures, such as another psychological test of personality, or a cognitive maturity scale, which could serve as a complementary observation parameter of the children's level of maturity. Studies that correlate the results of additional tests can enhance the way of understanding the organization of the development in children's personality, assessed through the Zulliger test (CS). In that sense, further research should be undertaken to fill this gap, which promotes comparison with other age groups, with a view to delimiting in further detail how maturing happens in function of chronological advances. In addition, in future research, the gender variable should be considered instead of sex. Despite the limits inherent in this study, the findings discussed here are considered relevant to demonstrate evidence of the validity of the test for the child assessment process, substantially contributing to understand how children develop their maturity for interpersonal relationship, whether in function of sex or their age range.

\section{References}

Cohen, J. (1992). A power primer. Psychological Bulletin, 112(1), 155-159. doi:10.1037/0033-2909.112.1.155

Davoglio, T. R., Gauer, G J. C., Jaeger, J V. H., \& Tolotti, M. D. (2012). Personalidade e psicopatia: Implicações diagnósticas na infância e adolescência [Personality and psychopathy: Diagnostic implications in childhood and adolescence]. Estudos de Psicologia (Natal), 17(3), 453460. doi:10.1590/S1413-294X2012000300014

Exner, J. E., Jr., \& Sendín, C. (1999). Manual de interpretação do Rorschach para o Sistema Compreensivo [Rorschach interpretation manual for the Comprehensive System] (L. Y. Massuh, Trans.). São Paulo, SP: Casa do Psicólogo.

Fazendeiro, H. M. M., \& Novo, R. J. F. (2012). Versão coletiva do teste de Zulliger segundo o Sistema Compreensivo de Rorschach [Zulliger group test according to the Rorschach Comprehensive System]. Avaliação Psicológica, 11(3), 407-422. Retrieved from http://pepsic.bvsalud.org/pdf/ 
avp/v11n3/v11n3a08.pdf

Franco, R. R. C., \& Villemor-Amaral, A. E. (2012). O Zulliger e as constelações do Rorschach no Sistema Compreensivo [Zulliger and Constellations of the Rorschach applied in System-Comprehensive]. Avaliação Psicológica, 11(1), 141-152. Retrieved from http://pepsic.bvsalud.org/pdf/ avp/v11n1/v11n1a13.pdf

Garcia, A., \& Pereira, P. C. C. (2008). Amizade na infância: Um estudo empírico [Friendship in childhood: An empirical study]. PSIC - Revista de Psicologia da Vetor Editora, 9(1), 25-34. Retrieved from http://pepsic. bvsalud.org/pdf/psic/v9n1/v9n1a04.pdf

Grazziotin, J. B. D., \& Scortegagna, S. A. (2012). Zulliger e habilidade social: Evidências de validade no contexto empresarial [Zulliger and social skills: Validity evidences in business context]. Psicologia: Reflexão e Crítica, 25(1), 69-78. doi:10.1590/S0102-79722012000100009

Grazziotin, J. B. D., \& Scortegagna, S. A. (2013). Relacionamento interpessoal, produtividade e habilidades sociais: Um estudo correlacional [Interpersonal relationships, productivity and social skills: A correlational study]. Psico-USF, 18(3), 491-500. doi:10.1590/S1413-82712013000300015

Leitão,H.A. L. (1999). Diferenças sexuais no desenvolvimento da preocupação moral por outras pessoas: Um estudo empírico da expressão de emoções morais em crianças [Gender differences in the development or moral concern for others: An empirical investigation of children's expressions of moral emotions]. Psicologia: Reflexão e Crítica. 12(1), 21-46. doi:10.1590/S010279721999000100003

Malone, J. C., Stein, M. B., Slavin-Mulford, J., Bello, I., Sinclair, S. J., \& Blais, M. A. (2013). Seeing red: Affect modulation and chromatic color responses on the Rorschach. Bulletin of the Menninger Clinic, 77(1), 7093. doi:10.1521/bumc.2013.77.1.70

Meyer, G. J., Viglione, D. J., Mihura, J. L., Erard, R. E., \& Erdberg, P. (2011). Rorschach performance assessment system: Administration, coding, interpretation, and technical manual. Toledo, $\mathrm{OH}$ : Rorschach Performance Assessment System.

Nunes, M. L. T., Teixeira, R. C. P., \& Deakin, E. K. (2010). Técnicas projetivas e avaliação de psicoterapia psicanalítica com crianças [Projective techniques and evaluation of psychoanalytic psychotherapy in children]. In M. L. T. Nunes (Org.), Técnicas projetivas com crianças [Projective techniques in children] (pp. 145170). São Paulo, SP: Casa do Psicólogo.

Pérez-Ramos, A. L. M. Q. (2000). Avaliação prospectiva: $\mathrm{O}$ exame precoce da criança [Prospective assessment: The child early examination]. In J. A. Cunha, Psicodiagnóstico-V [Psychodiagnosis-V] (pp. 151-157). Porto Alegre, RS: Artmed.

Rorschach, H. (1978). Psicodiagnóstico. Método e resultados de uma experiência diagnóstica de percepção (interpretação de formas fortuitas) [Psychodiagnosis. Method and results of a diagnostic experience of perception (interpretation of fortuitous shapes)] (M. S. Villemor-Amaral, Trans., 3rd ed.). São Paulo, SP: Mestre Jou. (Original work published 1921)

Schelini, P. W., Gomes, V. L. T., \& Wechsler, S. M. (2006). Avaliação psicológica infantil: Aspectos cognitivos e neuropsicológicos [Children's psychological assessment: Cognitive and neuropsychological aspects]. In A. P. Noronha, A. A. A. Santos \& F. F. Sisto (Orgs.), Facetas do fazer em avaliação psicológica [Facets of doing in psychological assessment] (pp. 81-94). São Paulo, SP: Vetor.

Tavella, R. R., \& Villemor-Amaral, A. E. (2014). O teste de Zulliger-SC: Avaliação da criatividade em crianças [The Zulliger-SC test: Assessment of children's creativity]. Estudos de Psicologia (Campinas), 31(4), 489-497. doi:10.1590/0103-166X2014000400003

Viglione, D. J., Perry, W., Giromini, L., \& Meyer, G. J. (2011). Revising the Rorschach Ego Impairment Index to accommodate recent recommendations about improving Rorschach validity. International Journal of Testing, 11(4), 349-364. doi:10.1080/15305058.2011.589019

Villemor-Amaral, A. E., \& Machado, M. A. S. (2011). Indicadores de depressão do Zulliger no Sistema Compreensivo (ZSC) [The depression index in the Zulliger Comprehensive System (ZSC)]. Paidéia (Ribeirão Preto), 21(48), 21-27. doi:10.1590/S0103863X2011000100004

Villemor-Amaral, A. E., \& Primi, R. (2009). Teste de Zulliger no Sistema Compreensivo - ZSC: Forma individual [Zulliger test in the Comprehensive System - ZSC: Individual form]. São Paulo, SP: Casa do Psicólogo.

Villemor-Amaral, A. E., \& Quirino, G. S. (2013). Estudo comparativo entre indicadores afetivos das técnicas de Pfister e Zulliger [Comparative study between the affective indicators of Zulliger and Pfister tests]. Avaliação Psicológica, 12(1), 1-7. Retrieved from http:// pepsic.bvsalud.org/pdf/avp/v12n1/v12n1a02.pdf

Weiner, I. B. (2000). Princípios da interpretação do Rorschach [Principles of Rorschach interpretation] (M. C. V. M. Silva, Trans.). São Paulo, SP: Casa do Psicólogo.

Ana Elisa Villemor-Amaral is a Professor at Universidade São Francisco.

Philipe Gomes Vieira is a Ph.D. candidate of the Graduate Program in Psychology at the Universidade São Francisco.

Received: July 27, 2015

1st Revision: Oct. 22, 2015

2nd Revision: Dec. 7, 2015

Approved: Dec. 9, 2015

How to cite this article:

Villemor-Amaral, A. E., \& Vieira, P. G. (2016). Zulliger (CS) in assessing the relational maturity of children. Paidéia (Ribeirão Preto), 26(65), 369-376. doi:10.1590/198243272665201601 